\title{
FRANCHISING IN THE HEALTHCARE \& FITNESS INDUSTRY
}

\author{
Milica Stanković ${ }^{1}$ \\ The Academy of Applied Technical and Preschool Studies - Vranje \\ Department, Serbia \\ Stevan Simić \\ Heavy B Consulting, Niš, Serbia
}

\begin{abstract}
The trend of development and expansion of healthcare and fitness franchises in the world is becoming a global phenomenon, having in mind the advantages that franchising as a business concept provides in relation to starting your own business. Healthcare and fitness clubs are increasingly deciding to enter the foreign market by using franchising as an internationalization strategy with the aim of minimizing costs and business risks. Most of the healthcare and fitness franchise companies come from the USA, but there is also a noticeable trend in the development of healthcare and fitness franchises on a global level. The paper analyzes healthcare and fitness franchise companies that are ranked on the list of top 500 franchises for 2020 according to magazine Entrepreneur. The aim of the paper is to determine the impact of internal factors, the size and the age of the franchise company, on the implementation of franchising as a strategy of internationalization for franchisors in healthcare and fitness industry.
\end{abstract}

Keywords: franchising, franchisor, franchisee, fitness industry, healthcare industry

\section{INTRODUCTION}

Over the five years to 2020, the healthcare fitness industry has experienced big gains due to growing membership levels and a more health-conscious population. However, there is an unexpected drop in revenue in the healthcare and fitness industry in 2020 due to the COVID19 pandemic. Consequently, industry revenue has decreased at an annualized rate of $2.8 \%$ to $\$ 3.0$ billion over the five years to 2020 , primarily as a result of an expected decline of $28.0 \%$ in 2020 alone as establishments close due to the pandemic (IBIS World, 2020). LIFitness and healthcare clubs are expected to reach 230 million members by 2030 . In addition, the U.S. Bureau of Labor Statistics Occupational Outlook handbook projects that employment of fitness trainers and instructors will grow 13\% from 2018 to 2028. This is faster than the average for other occupations (Jeff Franchise, 2020). The paper analyzes healthcare and fitness franchise companies that are ranked on the list of top 500 franchises for 2020 according to magazine Entrepreneur. The aim of the paper is to determine the impact of internal factors, the size and the age of

${ }^{1}$ milica.stankovic@akademijanis.edu.rs

Vol. 23, бpoj 2/2021, cmp. 19-32 
the franchise company, on the implementation of franchising as a strategy of internationalization for franchisors in healthcare and fitness industry.

\section{LITERATURE REVIEW}

The United States is the largest healthcare and fitness market in the world, not only in terms of income, but also in terms of the number of healthcare and fitness clubs members. According to the IHRSA, the $\$ 30$ billion health and fitness industry in the U.S. has been growing by at least $3-4 \%$ annually for the last ten years and shows no signs of slowing down soon (IHRSA, 2020). Currently, about $20 \%$ of American adults have a membership in healthcare or fitness club, and the average membership fee is $517 \$$ per year. The number of individuals who have a gym membership has increased by $37.1 \%$ from 2018 until today. It is expected that this number could easily double in the next 10-15 years (Workout Anytime, 2021). Fitness and healthcare clubs usually have a constant source of income, bearing in mind that membership is paid at the beginning of the month, regardless of the number of trainings and hours of using healthcare and fitness services. On average, members visited their healthcare and fitness clubs for 102 days annually (Franchise Opportunities, 2021).

The global increase in overweight and obesity has been evident in recent decades and has become extremely widespread in both developed and developing countries, leading to a modern "obesity epidemic" (Shirasava et al., 2015; Forouzanfar et al. 2016; Hurbo et al. al., 2018; Psaltopoulou et al., 2019; Đošić et al., 2019). Weight gain has a negative effect on people's physical and mental health (Wasiluk \& Saczuk, 2020; Strong et al., 2005). The research results so far show that fitness is an excellent indicator and predictor of health in later life (Cvejić et al., 2013; Madić et al., 2018; Živković et al., 2018). Interest in sports activities, including fitness, has increased in recent years due to the fact that general health can be improved by improving physical fitness (Đokić et al., 2014). In 2015, the Centers for Disease Control and Prevention (CDC) reported that $70.7 \%$ of U.S. adults age 20 and over were either obese or overweight based on a standard weight-for-height measurement called body mass index (BMI). In 2015, the CDC also reported that one-third of U.S. children between the ages of 2 and 19 were obese or overweight. Although the number of adults and children with overweight and obesity is increasing every year, there is a noticeable trend of using fitness services (Franchise Opportunities, 2021).

The trend of development and expansion of healthcare and fitness franchises continues, having in mind a number of advantages that 
franchising as a business concept offers in relation to starting your own business. Fitness and healthcare franchisors give their franchisees the right to operate according to a tried and tested business model, in exchange for the initial fee for entering the franchise system and royalties, which are usually paid monthly. This minimizes the risk of entering the fitness industry by using an already established recognizable brand (Stebbins, 2020). The franchisor provides the franchisee with both initial training and continuous additional support throughout the duration of the franchise agreement (Pearson, 2017; Franchise Help, 2021).

According to the IBISWorld 2018 Gym \& Fitness Franchises Report, healthcare and fitness are one of the fastest growing sectors in the franchise world (Franchise Direct, 2018). Data from the franchise healthcare and fitness industry point to the fact that healthcare and fitness clubs that are part of the franchise system operate with much better results than healthcare and fitness clubs that are not part of the franchise chain (Franchise Opportunities, 2021). In the Entrepreneur list of Top 20 Fastest Growing Franchises, there are as many as 4 franchise systems from the healthcare and franchise sector (Entrepreneur, 2020). However, the trend of development and expansion of healthcare and fitness clubs is not limited to the USA. There are numerous healthcare and fitness franchises in Europe and Australia that have been operating successfully for many years. In addition, Asia represents a huge market for healthcare and fitness franchises with over 2.8 billion potential customers, and countries like China, India or Russia can expect the largest growth in healthcare and fitness club members in the coming years (Global Franchise, 2019).

Fitness and healthcare clubs rarely decide to internationalize using their own resources, bearing in mind that this requires a lot of capital. In this regard, healthcare and fitness clubs are increasingly applying nonequity models of entering international markets, all with the aim of minimizing costs and business risks. It is therefore important to point out the importance of franchising as an internationalization strategy in the healthcare and fitness sector. Globally, franchising is one of the fastest growing business strategies, given that it allows franchisors to develop a franchise system with minimal capital investment. Franchising provides the opportunity for rapid international expansion for healthcare and fitness clubs and has the potential to overcome many of the cultural, linguistic, technical, legal, and employment issues commonly associated with internationalization. Internationalization through franchising can be a complex process influenced by a number of factors. Most research to date has focused on the analysis of factors influencing internationalization through franchising in the manufacturing sector and in the fast food 
sector, but in the healthcare and fitness sector more attention needs to be paid to this topic. Huszagh, Huszagh \& McIntyre (1992) found that the age of the company (expressed by the number of years of franchise business) and the size of the company (expressed by the number of franchises) are significant factors influencing the implementation of franchising as an internationalization strategy. The aim of this paper is to point out the importance of franchising in the healthcare and fitness sector and to determine the influence of internal factors in the field of size and age of healthcare and fitness franchises on internationalization through the implementation of franchising.

\section{METHODS}

The subject of the study is international franchising in the healthcare and fitness industry. The purpose of the research is to determine the influence of internal factors from the domain of the size and age of the healthcare and fitness franchise companies on implementation of franchising as a strategy of internationalization. This paper attempts to answer the following research questions: Do the internal factors have an impact on the implementation of franchising as a strategy of internationalization by the healthcare and fitness franchise companies? Does the size of the healthcare and fitness franchise company, measured by the total number of franchise units, influence the decision to implement franchising as a strategy for entering the foreign markets? Does the age or experience of healthcare and fitness franchise company, measured by the number of years in franchise business, have an impact on the implementation of franchising as a strategy of internationalization? Based on these research questions, the following hypotheses are defined:

H1: Internal factors from the domain of the characteristics of the healthcare and fitness franchise company have an impact on the implementation of franchising as a strategy of internationalization

H2: The size of healthcare and fitness franchise company has an impact on the implementation of franchising as a strategy of internationalization.

H3: The age of healthcare and fitness franchise company has an impact on the implementation of franchising as a strategy of internationalization.

Considering that the academic community still insufficiently writes about international franchising in the healthcare and fitness industry, especially about the factors that influence the choice of franchising as a strategy of internationalization, we recognize the need to devote special attention to this topic. The subjects of research are 
healthcare and fitness franchise companies which are ranked on Entrepreneur magazine's list 2020 Top 500 Franchises. There are 18 healthcare and fitness franchisors on this list. The proposed hypotheses are confirmed based on the analysis of secondary data about a given healthcare and fitness franchisors, using the software package SPSS. The number of international franchise units (i.e. franchise units outside the U.S.) of each healthcare and fitness franchise chain from the sample is used as the dependent variable. The independent variables are internal factors from the domain of the size and age of the healthcare and fitness franchise company. The healthcare and fitness franchise company's size is observed through the total number of franchise units, while the healthcare and fitness franchise company's age (i.e. experience) is determined by the number of years in franchise business.

In accordance with the defined object and purpose of survey, proper theoretical and empirical research methods were used in the paper. Descriptive analysis was used for understanding the state of activity of healthcare and fitness franchise chains that implement franchising as a strategy of internationalization. Statistical analysis of secondary data was performed using the SPSS software package. Statistical techniques for the investigation of connections and relationships between variables: correlation analysis and simple and multiple linear regression were used to verify the hypotheses.

\section{RESULTS AND DISCUSSION}

The fact that there are 18 franchises from the healthcare and fitness industry on the list 2020 Top 500 Franchises, indicates the importance of this sector in the field of franchising. It is important to mention that the seventh company on this list is franchise company Planet Fitness, which has over 2.000 franchise units all over the world. In addition, there are six healthcare and fitness franchise chains in the top 100 companies on the list of Top 500 Franchises: Planet Fitness, Anytime Fitness, Fyzical Therapy \& Balance Centers, Orangetheory Fitness, F45 Training (Table 1).

The oldest healthcare and fitness franchise company on the list 2020 Top 500 franchises is Gold's Gym, which was founded in 1965, while the youngest franchise system in the healthcare and fitness industry from this list started the business 6 years ago (Tapout Fitness). Observed by the number of years in franchise business, fitness club Gold's Gym has used franchise business model since 1980, i.e. for 40 years. The youngest companies in terms of franchise business are Tapout Fitness and Burn

Vol. 23, бpoj 2/2021, cmp. 19-32 
Boot Camp, which have used franchise business model for only 5 years (Table 2).

Table 1.: The ranking of healthcare and fitness franchise companies on the list 2020 Top 500 Franchises

\begin{tabular}{|l|l|}
\hline Rank & Company \\
\hline 7 & Planet Fitness \\
\hline 22 & Anytime Fitness \\
\hline 33 & Fyzical Therapy \& Balance Centers \\
\hline 43 & Orangetheory Fitness \\
\hline 68 & F45 Training \\
\hline 69 & Club Pilates Franchise \\
\hline 179 & The Little Gym Int'l. \\
\hline 202 & My Gym Children's Fitness Center \\
\hline 212 & Burn Boot Camp \\
\hline 274 & GYMGUYZ \\
\hline 351 & Workout Anytime 24/7 \\
\hline 367 & Kinderdance Int'l. Inc. \\
\hline 408 & Tapout Fitness \\
\hline 427 & Gold's Gym \\
\hline 437 & Fit Body Boot Camp \\
\hline 469 & Snap Fitness Inc. \\
\hline 473 & Retro Fitness \\
\hline 499 & UFC Gym \\
\hline & Source: Entrepreneur, 2020. \\
\hline
\end{tabular}

The total number of franchise units ranges from 28 in the case of company Tapout Fitness to even 4.743 franchise units, in case of fitness club Anytime Fitness. The average number of franchise units in healthcare and fitness franchise chains that are on the list 2020 Top 500 Franchise is 833 franchise units. There are five largest healthcare and fitness franchise systems that have over 1,000 franchise units: Snap Fitness Inc. (1.267 franchise units), F45 Training (1.298), Orangetheory Fitness (1.385), Planet Fitness (2.059) and Anytime Fitness (4.743). The number of international franchise units ranges from 0 to 2.327 (in the case of company Anytime Fitness). Even 7 of the 18 fitness franchise chains (39\%) have more than 100 international franchise units (Table 2).

The initial investment required to start a business within one of the healthcare and fitness franchise chains that are on the list 2020 Top 500 Franchises ranges from $18.150 \$$ (fitness club for kids Kinderdance Int'1 
Inc.) to 5.000.500\$ (Gold's Gym). The average initial investment required to start a business within one of the famous healthcare and fitness franchise company is $816.077 \$$. The initial franchise fee ranges between $25.000 \$$ (Kinderdance Int'l Inc.) and 70.000\$ (Fyzical Therapy \& Balance Centers). The average initial franchise fee is $41.253 \$$. The ongoing fee (royalty) ranges from 5\% (Gold's Gym and Retro Fitness) to $12 \%$ (Kinderdance Int'l Inc.) (Table 2).

Table 2.: Descriptive analysis of healthcare and fitness franchise systems

\begin{tabular}{|l|l|l|l|}
\hline & Minimum & Maximum & Mean \\
\hline Number of years in business & 6 & 55 & 21 \\
\hline $\begin{array}{l}\text { Number of years in franchise } \\
\text { business }\end{array}$ & 5 & 40 & 16 \\
\hline Total number of franchise units & 28 & 4.743 & 833 \\
\hline $\begin{array}{l}\text { Number of international franchise } \\
\text { units (franchise units outside } \\
\text { U.S.) }\end{array}$ & 0 & 2.327 & 295 \\
\hline Initial investition & 18.150 & 5.000 .500 & 816.077 \\
\hline Initial franchisee fee & 15.000 & 70.000 & 41.253 \\
\hline Ongoing royalty fee & $5 \%$ & $12 \%$ & $6 \%$ \\
\hline
\end{tabular}

In accordance with the defined aim of the study, we will observe the impact of the internal factors (healthcare and fitness franchise company's size and age) on the implementation of franchising as a strategy of internationalization. First of all, simple linear regression will be conducted in order to examine the impact of each of these internal factors on the implementation of franchising as a strategy of internationalization. Then, common impact of the healthcare and fitness franchise company's size and age on the implementation of franchising as a strategy of internationalization will be examined by using multiple linear regression. Pearson's correlation coefficient indicates that there is a strong positive correlation between the size of the healthcare and fitness franchise company and the implementation of franchising as a strategy of internationalization, $r=0,887$. This result is statistically significant, $\mathrm{p}=0,000$.

We can conclude that there is a statistically significant strong positive correlation between the healthcare and fitness franchise company's size (total number of franchise units) and implementation of franchising as a strategy of internationalization (number of international franchise units) $(\mathrm{r}=0,887, \mathrm{p}<0,005)$. It can be concluded that larger healthcare and fitness clubs prefer to use franchising as an internationalization strategy. The coefficient of determination in this case 
is $\mathrm{R} 2=0,787$, so the size of the healthcare and fitness franchise company explains $78,7 \%$ of variance in the answers relating to the use of franchising as a strategy of internationalization. This regression model reaches statistical significance $(\mathrm{F}=59,111, \mathrm{p}=0,000)$ (Table 3$)$.

Table 3.: Results of simple linear regression - the impact of the healthcare and fitness franchise company's size on the implementation of franchising as a strategy of internationalization

Correlations

\begin{tabular}{|c|c|c|c|}
\hline & & $\begin{array}{l}\text { Number of } \\
\text { international franchise } \\
\text { units }\end{array}$ & $\begin{array}{l}\text { Total number of } \\
\text { franchise units }\end{array}$ \\
\hline \multirow[t]{2}{*}{$\begin{array}{l}\text { Pearson } \\
\text { Correlation }\end{array}$} & $\begin{array}{l}\text { Number } \\
\text { international } \\
\text { franchise units }\end{array}$ & 1,000 & 0,887 \\
\hline & $\begin{array}{l}\text { Total number of } \\
\text { franchise units }\end{array}$ & 0,887 & 1,000 \\
\hline \multirow[t]{2}{*}{ Sig. } & $\begin{array}{l}\text { Number } \\
\text { international } \\
\text { franchise units }\end{array}$ & , & 0,000 \\
\hline & $\begin{array}{l}\text { Total number of } \\
\text { franchise units }\end{array}$ & 0,000 & \\
\hline
\end{tabular}

Model Summary

\begin{tabular}{llrrr} 
Model & R & & R Square & Adjusted R Square \\
\hline 1 & & 0,887 & 0,787 & 0,774 \\
\hline
\end{tabular}

\begin{tabular}{|c|c|c|c|c|c|}
\hline \multirow[t]{2}{*}{ ANOVA } & \multirow[b]{2}{*}{$\begin{array}{l}\text { Sum } \\
\text { Squares }\end{array}$} & \multirow[b]{2}{*}{ df } & \multirow[b]{2}{*}{$\begin{array}{l}\text { Mean } \\
\text { Square }\end{array}$} & \multirow[b]{2}{*}{$\mathbf{F}$} & \multirow[b]{2}{*}{ Sig. } \\
\hline & & & & & \\
\hline Regression & 4279129,043 & 1 & 4279129,043 & 59,111 & 0,000 \\
\hline Residual & 1158256,957 & 16 & 72391,060 & & \\
\hline Total & 5437386.000 & 17 & & & \\
\hline
\end{tabular}

\begin{tabular}{llllll}
$\begin{array}{l}\text { Coefficients } \\
\text { Model }\end{array}$ & B & $\begin{array}{l}\text { Std. } \\
\text { Error }\end{array}$ & Beta & t & Sig. \\
\hline $\begin{array}{l}\text { (Constatnt) } \\
\begin{array}{l}\text { Total number } \\
\text { franchise units }\end{array}\end{array}$ & $\begin{array}{l}-77,132 \\
0,447\end{array}$ & $\begin{array}{l}79,778 \\
0,058\end{array}$ & 0,887 & 7,688 & 0,000 \\
\hline
\end{tabular}

Source: Authors

Simple linear regression will be conducted in order to determine the effect of the healthcare and fitness franchise company's age on the implementation of franchising as a strategy of internationalization. 
Pearson's correlation coefficient indicates that there is a weak positive correlation between the age of the healthcare and fitness franchise company and the implementation of franchising as a strategy of internationalization, $r=0,146$. This result is not statistically significant, $\mathrm{p}=0,564$. The conclusion is that there is a weak positive correlation between the healthcare and fitness franchise company's age (number of years in franchise business) and implementation of franchising as a strategy of internationalization (number of international franchise units) that is not statistically significant. The coefficient of determination in this case is $\mathrm{R} 2=0,021$, so the age of the healthcare and fitness franchise company explains just $2,1 \%$ of variance in the answers relating to the use of franchising as a strategy of internationalization. This regression model does not reach statistical significance $(\mathrm{F}=0,348, \mathrm{p}=0,564)$ (Table 4).

Table 4.: Results of simple linear regression - the impact of the healthcare and fitness franchise company's age on the implementation of franchising as a strategy of internationalization

Correlations

\begin{tabular}{|c|c|c|c|}
\hline 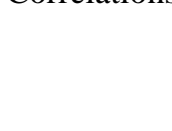 & & $\begin{array}{l}\text { Number } \\
\text { international } \\
\text { franchise units }\end{array}$ & $\begin{array}{l}\text { Number of years in } \\
\text { franchise business }\end{array}$ \\
\hline \multirow[t]{2}{*}{$\begin{array}{l}\text { Pearson } \\
\text { Correlation }\end{array}$} & $\begin{array}{ll}\text { Number } & \text { of } \\
\text { international } & \\
\text { franchise units } & \\
\end{array}$ & 1,000 & 0,146 \\
\hline & $\begin{array}{l}\text { Number of years in } \\
\text { franchise business }\end{array}$ & 0,146 & 1,000 \\
\hline \multirow[t]{2}{*}{ Sig. } & $\begin{array}{l}\text { Number of } \\
\text { international } \\
\text { franchise units }\end{array}$ & , & 0,564 \\
\hline & $\begin{array}{l}\text { Number of years in } \\
\text { franchise business }\end{array}$ & 0,564 & , \\
\hline
\end{tabular}

Model Summary

\begin{tabular}{lrrrr} 
Model & R & R Square & Adjusted R Square & \\
\hline 1 & & 0,146 & 0,021 & $-0,040$ \\
\hline
\end{tabular}

\begin{tabular}{|c|c|c|c|c|c|}
\hline $\begin{array}{l}\text { ANOVA } \\
\text { Model }\end{array}$ & $\begin{array}{l}\text { Sum } \\
\text { Squares }\end{array}$ & df & $\begin{array}{l}\text { Mean } \\
\text { Square }\end{array}$ & $\mathbf{F}$ & Sig. \\
\hline Regression & 115664,094 & 1 & 115664,094 & 0,348 & 0,564 \\
\hline Residual & 5321721,906 & 16 & 332607,619 & & \\
\hline Total & 5437386,000 & 17 & & & \\
\hline
\end{tabular}

Coefficients

\begin{tabular}{llllll} 
Model & B & Std. Error & Beta & $\mathbf{t}$ & Sig. \\
\hline
\end{tabular}


Милица Станковић, Стеван Симић

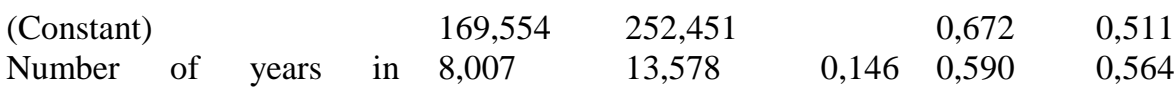

franchise business

Source: Authors

The regression model that includes internal factors from the domain of healthcare and fitness franchise company's size and age reaches statistical significance $(\mathrm{F}=29,216, \mathrm{p}=0,000)$. Beta coefficient is higher for variable total number of franchise units $(B e t a=0,882)$, so the size of the healthcare and fitness franchise company contribute more to the explanation of the dependent variable than the age of the healthcare and fitness franchise company (Table 5).

Table 5.: Results of multiple linear regression - the impact of the healthcare and fitness franchise company's size and age on the implementation of franchising as a strategy of internationalization

Model Summary

\begin{tabular}{lllr} 
Model & R & R Square & Adjusted R Square \\
\hline 1 & 0,892 & 0,796 & 0,768 \\
\hline
\end{tabular}

\begin{tabular}{llllll} 
ANOVA & Sum of Squares & df & $\begin{array}{l}\text { Mean } \\
\text { Square }\end{array}$ & F & Sig. \\
\hline Regression & 4326687,206 & 2 & 2163343,603 & 29,216 & 0,000 \\
Residual & 1110698,794 & 15 & 74046,586 & & \\
Total & 5437386,000 & 17 & & &
\end{tabular}

\begin{tabular}{|c|c|c|c|c|c|}
\hline $\begin{array}{l}\text { Coefficients } \\
\text { Model }\end{array}$ & $\mathbf{B}$ & Std. Error & Beta & $\mathbf{t}$ & Sig. \\
\hline (Constant) & $-155,387$ & 126,668 & & $-1,227$ & 0,239 \\
\hline Total number of franchise & 0,444 & 0,059 & 0,882 & 7,541 & 0,000 \\
\hline $\begin{array}{l}\text { units } \\
\text { Number of years in } \\
\text { franchise business }\end{array}$ & 5,143 & 6,418 & 0,094 & 0,801 & 0,435 \\
\hline
\end{tabular}

Source: Authors

Based on a comprehensive analysis, it can be concluded that there is statistically significant strong positive correlation between the healthcare and fitness franchise company's size and the implementation of franchising as a strategy of internationalization. The regression model that explains the impact of the healthcare and fitness franchise company's size on the implementation of franchising as a strategy of internationalization 
reaches statistical significance. Therefore, we confirm the hypothesis that the size of the healthcare and fitness franchise companies has an impact on the implementation of franchising as a strategy of internationalization. There is a weak positive correlation between the age of the healthcare and fitness franchise companies and the use of franchising for international expansion, but it is not statistically significant. The regression model that explains the impact of the healthcare and fitness franchise company's age on the implementation of the franchising as a strategy of internationalization does not reach statistical significance. Therefore, we can not confirm the assumption that the age of the healthcare and fitness franchise company has an impact on the implementation of franchising as a strategy of internationalization. The regression model that includes internal factors from the domain of the healthcare and fitness franchise company's size and age explains $79,6 \%$ of variance in the answers concerning the implementation of franchising as a strategy of internationalization and this model reaches statistical significance $(\mathrm{F}=29,216, \mathrm{p}=0,000)$. The hypothesis that the internal factors from the domain of healthcare and fitness franchise company's characteristics have an impact on the implementation of franchising as a strategy of internationalization is confirmed.

\section{CONCLUSION}

Franchising is one of the fastest growing business strategies, as it allows franchisors to develop a franchise system with minimal investment. The trend of development and expansion of healthcare and fitness franchises in the world is becoming a global phenomenon, having in mind a number of advantages that franchising as a business concept offers in relation to starting your own business. Fitness and healthcare clubs rarely opt for internationalization using their own resources, but increasingly apply non-equity models of entering international markets in order to minimize costs and business risks. The paper analyzes healthcare and fitness franchise companies that are ranked on the Entrepreneur list 2020 Top 500 Franchises. Based on the conducted statistical analysis, it is found that there is a statistically significant strong positive correlation between the size of healthcare and fitness franchise system (total number of franchise units) and the implementation of the franchising as a strategy for internationalization (number of international franchise units), and there is weak positive correlation between the age of healthcare and fitness franchise system (number of years in franchise business) and internationalization by using franchising, but it is not statistically significant. The limitation of the study is that the focus is only on the 
impact of internal factors on the implementation of franchising as a strategy of internationalization by the healthcare and fitness franchise companies. The future studies should, in addition to internal factors, include the analysis of external factors, primarily cultural and geographic distance. This study refers to healthcare and fitness franchise companies from the U.S., so future studies might deal with the analysis of international franchising in the European healthcare and fitness industry and comparative analysis in a several different countries.

\section{REFERENCES}

1. Cvejić, D., Pejović, T., \& Ostojić, S. (2013). Assessment of physical fitness in children and adolescents. Facta Universitatis Series Physical Education and Sport, 11(2), 135-145.

2. Đokić, Z., Jovanović, D., Kondrič, M. (2014). Health related physical fitness levels of the elderly, Facta Universitatis Series Physical Education and Sport, 12(1), 19-29.

3. Đošić, A., Bratić, M., Jezdimirović, M., Purenović-Ivanović, T., Živković, D., Bratić, M. (2019). Fitness parameters and morphological characteristics of overweight and obese children aged seven, Facta Universitatis Series Physical Education and Sport, 17(3), 549-558.

4. Entrepreneur (2020). 2020 Fastest-Growing Franchises Ranking, Dostupno na: https://www.entrepreneur.com/franchises/fastestgrowing (pristupljeno: 08.01.2021.)

5. Forouzanfar, M.H., Afshin, A., Alexander, L.T., Anderson, H.R., Bhutta, Z.A., Biryukov, S. al. (2016). Global, regional, and national comparative risk assessment of 79 behavioural, environmental and occupational, and metabolic risks or clusters of risks, 1990-2015: a systematic analysis for the Global Burden of Disease Study 2015. Lancet, 1659-1724

6. Franchise Direct (2018). Fitness Franchise Industry Report 2018, Dostupno na: https://www.franchisedirect.com/information/fitnessfranchise-industry-report-2018 (pristupljeno: 15.01.2021.)

7. Franchise Help (2021). Fitness Industry Analysis 2020 - Cost \& Trends, Dostupno na: https://www.franchisehelp.com/industryreports/fitness-industry-analysis-2020-cost-trends/ (pristupljeno: 08.01.2021.)

8. Franchise Opportunities (2021). Health \& Fitness Industry Outlook And Trends,

Dostupno na: 
https://www.franchiseopportunities.com/industry-profile/health-andfitness-industry (pristupljeno: 08.01.2021.)

9. Global Franchise (2019). Why fitness franchising is exploding, and how you can get involved, Dostupno na: https://www.globalfranchisemagazine.com/news/why-fitnessfranchising-is-exploding-and-how-you-can-get-involved (pristupljeno: 14.01.2021.)

10. Hurbo. T., Skryhan, H., Radyhina, V., \& Pamazanau, M. (2018). Underweight, overweight and obesity in children and adolescents from Minsk, Belarus in the period 2001-2008. Anthropologischer Anzeiger, 75(2), 89-100.

11. Huszagh, S.M., Huszagh, F.W., McIntyre, F.S. (1992). International franchising in the context of competitive strategy and the theory of the firm. International Marketing Review, 9(5), 5-18.

12. IBIS World (2020). Gym \& Fitness Franchises in the US industry trends (2015-2020), Dostupno na: https://www.ibisworld.com/unitedstates/market-research-reports/gym-fitness-franchises-industry/ (pristupljeno: 15.01.2021.)

13. IHRSA (2020). 2019 Fitness Industry Trends Shed Light on 2020 \& Beyond, Dostupno na: https://www.ihrsa.org/improve-yourclub/industry-news/2019-fitness-industry-trends-shed-light-on-2020beyond/ (pristupljeno: 14.01.2021.)

14. Jeff Franchise (2020). Fitness industry market: The profitable investment in the health and wellness industry, Dostupno na: https://franchise.wearejeff.com/news/fitness-industry-market-theprofitable-investment-in-the-health-and-wellness-industry (pristupljeno: 14.01.2021)

15. Madić, D., Cvetković, M., Popović, B., Marinković, D., Radanović, D., Trajković, N. (2018). Effects of developmental gymnastics on motor fitness in preschool girls, Facta Universitatis Series Physical Education and Sport, 16(1), 11-18.

16. Pearson, E. (2017). Fitness Franchises Offer Strong Advantages, Dostupno na: https://www.franchising.com/articles/fitness_franchises_offer_strong_ advantages.html (pristupljeno: 14.01.2021.)

17. Psaltopoulou, T., Tzanninis, S., Ntanasis-Stathopoulos, I., Panotopoulos, G., Kostopoulou, M., Tzanninis, I. G., et al. (2019). Prevention and treatment of childhood and adolescent obesity: a systematic review of meta-analyses. World Journal of Pediatrics, 15(4), 350-381.

18. Shiraswa, T., Ochiai, N., Nanri, H., Hirotaka, O., Hinako, N., Rimei, N., et al. (2015). Trends of underweight and overweight/obesity 
among Japanese schoolchildren from 2003 to 2012, defined by body mass index and percentage overweight cut-offs. Journal of Epidemiology, 25(7), 482-488.

19. Stebbins, S. (2020). Franchises that work out: Many of the hottest US businesses to franchise involve fitness, Dostupno na: https://www.usatoday.com/story/money/2020/02/15/hottestbusinesses-to-franchise-in-america/41222575/ (pristupljeno: 05.01.2021.)

20. Strong, W. B., Malina, R. M., Blimkie, C. J., Daniels, S. R., Dishman, R. K., Gutin, B., Rowland, T. (2005). Evidence based physical activity for school-age youth. The Journal of Pediatrics, 146(6), 732737.

21. Wasiluk, A., Saczuk, J. (2020). Physical fitness of boys pertaining to underweight, overweight and obesty, Facta Universitatis Series Physical Education and Sport, 18(1), 229-238.

22. Workout Anytime (2021). The opportunity: Our industry, Dostupno na: https://workoutanytimefranchise.com/the-opportunity/ourindustry/ (pristupljeno: 15.01.2021.)

23. Živković, D., Ranđelović, N., Đrorđević, M., Pantelić, S., Malobabić, M. (2018). Relations of fitness parameters and morphological characteristics of seven year old obese children, Facta Universitatis Series Physical Education and Sport, 16(1), 1-9.

Рад је примљен: 18. новембра 2021. Рад је прихваћен за штампу: 30. новембра 2021. 